\title{
Pengaruh Faktor Risiko terhadap Waktu Timbulnya Efek Samping Kanamisin pada Tuberkulosis Resistan Obat
}

\author{
Martha Ratnawati, ${ }^{1}$ Reviono, ${ }^{1,2}$ Wachid Putranto, ${ }^{3}$ Yusup Subagio Sutanto, ${ }^{1,2}$ Harsini ${ }^{1,2}$ \\ ${ }^{1}$ Bagian Pulmonologi dan Kedokteran Respirasi Fakultas Kedokteran Universitas Sebelas Maret Surakarta, \\ Indonesia, ${ }^{2}$ KSM Paru RSUD Dr. Moewardi Surakarta, ${ }^{3}$ Bagian Penyakit Dalam Sub Bagian Ginjal Hipertensi \\ Fakultas Kedokteran Universitas Sebelas Maret/RSUD Dr. Moewardi Surakarta, Indonesia
}

\begin{abstract}
Abstrak
Kanamisin adalah obat untuk terapi tuberkulosis resistan obat (TB RO) yang menimbulkan efek samping gangguan pendengaran, gangguan fungsi ginjal, dan gangguan elektrolit terutama hipokalemia. Penelitian bertujuan menilai kesintasan waktu timbulnya efek samping dan pengaruh faktor risiko usia, riwayat terapi streptomisin serta berat badan terhadap efek samping akibat pemberian kanamisin pasien TB RO. Penelitian kohort retrospektif dari data rekam medis pasien TB RO dari Januari 2011 sampai April 2017 di RSUD Dr. Moewardi Surakarta. Analisis pengaruh faktor risiko terhadap efek samping menggunakan uji cox regression. Dari 238 pasien didapatkan gangguan pendengaran 143 pasien, gangguan fungsi ginjal 147 pasien, dan hipokalemia 169 pasien. Usia lebih dari 40 tahun hazard ratio (HR) 2,419 (IK: 95\%; 1,716-3,409; $\mathrm{p}=0,000$ ) dan jenis kelamin perempuan HR: 1,549 (IK: 95\%; 1,089-2,202; $\mathrm{p}=0,015$ ) berisiko terjadi gangguan pendengaran. Usia lebih dari 40 tahun HR: 1,892 (IK: 95\%; 1,353-2,646; p= 0,000) dan jenis kelamin perempuan HR: 1,667 (IK: 95\%; 1,179-2,357; p=0,004) berisiko terjadi gangguan fungsi ginjal. Riwayat streptomisin sebelumnya dan indeks massa tubuh (IMT) tidak berisiko timbul efek samping akibat pemberian kanamisin. Pengawasan ketat timbulnya efek samping gangguan pendengaran dan gangguan fungsi ginjal pasien usia lebih dari 40 tahun dan perempuan pada pengobatan TB RO.
\end{abstract}

Kata kunci: Efek samping, gangguan fungsi ginjal, gangguan pendengaran, kanamisin, TB resistan obat

\section{Effects of Risk Factors on the Onset of Kanamycin's Adverse Events in Drug Resistant Tuberculosis}

\begin{abstract}
Kanamycin is a therapy for drug-resistant tuberculosis (TB) which may cause hearing loss, impaired kidney function, and electrolyte disorders, especially hypokalemia. The objective of this study was to assess patient survival and the effects of risk factors such as age, previous history of streptomycin therapy, and weight on adverse events due to kanamycin administration in patients with drug resistant TB. A retrospective cohort study was conducted in TB patients by using medical records from January 2011 to April 2017 in Dr. Moewardi Hospital Surakarta. Cox regression analysis was used to analyze the relation between risk factors and adverse events. Of 238 patients, 143 patients experienced hearing loss, 147 patients experienced impaired kidney function, and 169 patients had hypokalemia. Age over 40 and female gender had higher risks for hearing loss and impaired kidney function (HR: 2.419 (95\% CI: 1.716-3.409; $p=0,000$ ) and HR: 1,892 (95\% CI: 1.353-2.646; p=0,000); HR: 1.549 (95\%CI: 1.089-2.202; p=0,015), and HR: 1.667 (95\% CI: 1.179-2.357; p=0.004)), respectively. History of streptomycin and body mass index (BMI) were not risk factors for kanamycin's adverse events. Therefore, closed monitoring on hearing loss and impaired kidney function is necessary for drug resistant TB patients aged over 40 , and female patients.
\end{abstract}

Key words: Adverse events, drug resistant tuberculosis, hearing loss, impaired kidney function, kanamycin

Korespondensi: Martha Ratnawati dr., Bagian Pulmonologi dan Kedokteran Respirasi Fakultas Kedokteran Universitas Sebelas Maret/RSUD Dr. Moewardi Jalan Kol. Soetarto 132 Surakarta, Email martha.bumiwana@gmail.com 


\section{Pendahuluan}

Obat antituberkulosis atau OAT merupakan komponen yang terpenting dalam pengobatan tuberkulosis (TB). Perkembangan selanjutnya ditemukan kuman TB resistan obat (RO). World Health Organization (WHO) merekomendasikan obat suntik lini kedua untuk pengelolaan TB RO, di antaranya adalah golongan aminoglikosida terdiri dari streptomisin, kanamisin, amikasin, dan juga golongan polipeptida kapreomisin. Kanamisin dapat menimbulkan efek samping yang berat, yaitu ototoksik, gangguan elektrolit (hipokalemia, hipomagnesemia, hipokalsemia), dan gangguan fungsi ginjal (nefrotoksik). ${ }^{1-3}$

Ototoksik oleh karena pemberian kanamisin dapat menimbulkan gangguan pendengaran (kokleotoksik) serta gangguan keseimbangan (vestibulotoksik). Kanamisin lebih dominan menyebabkan efek samping kokleotoksik berupa gangguan pendengaran dan atau tinnitus., ${ }^{4,5}$ Faktor risiko ototoksisitas adalah pemberian terapi $>7$ hari, riwayat pemakaian aminoglikosida sebelumnya, dosis tinggi harian, peningkatan kadar obat dalam serum, paparan suara bising, pemakaian usia sangat muda/tua dan mutasi deoxyribonucleic acid (DNA) mitokondria. ${ }^{6}$

Efek samping dari kanamisin pada ginjal merupakan kejadian yang sering. Nefrotoksik karena pemberian kanamisin diakibatkan oleh toksisitas di tubulus ginjal, penurunan filtrasi glomerulus dan penurunan aliran darah ke ginjal yang akhirnya menimbulkan gangguan fungsi ginjal ditandai nonoliguri, poliuri hipoosmotik serta peningkatan ureum dan kreatinin serum. ${ }^{7,8}$ Faktor risiko nefrotoksisitas di antaranya usia tua, penurunan fungsi ginjal sebelumnya, kehamilan, dehidrasi, dan kurang natrium. ${ }^{7}$ Kanamisin terakumulasi di tubulus proksimal dalam jangka lama juga menyebabkan gangguan keseimbangan elektrolit terutama hipokalemia. Faktor risiko gangguan elektrolit pasien TB RO meliputi kumulatif dosis, berat badan rendah, dan penggunaan kapreomisin. ${ }^{7,8}$

Penelitian bertujuan menganalisis kesintasan timbulnya efek samping kanamisin kepada pasien TB RO, yaitu gangguan pendengaran, gangguan fungsi ginjal dan hipokalemia. Analisis faktor risiko usia, riwayat terapi streptomisin sebelumnya, dan berat badan terhadap efek samping kanamisin pada pengobatan TB RO.

\section{Metode}

Penelitian ini merupakan penelitian kohort retrospektif dari data rekam medis pasien TB RO Januari 2011-April 2017 di RSUD Dr. Moewardi Surakarta. Teknik pengambilan sampel dengan total sampling yaitu semua populasi pasien TB RO dari bulan Januari 2011-April 2017. Kriteria inklusi adalah pasien TB RO dari bulan Januari 2011-April 2017 diterapi kanamisin pada rejimen TB RO. Kriteria eksklusi adalah catatan rekam medis pasien tidak ada/tidak lengkap, riwayat pemakaian kanamisin selama $\geq 1$ bulan dalam 6 bulan terakhir, gangguan pendengaran tipe sensory neural hearing loss (SNHL) saat base line, pasien meninggal atau tidak melanjutkan pengobatan (putus berobat, pindah) sebelum timbul efek samping dalam masa penelitian 8 bulan, pemakaian obat ototoksik (sisplatin, karboplatin, furosemid, bumetanid, hidrokodon, metadon, salisilat, kinin, klorokuin, hidroklorokuin, eritromisin, azitromisin, deferoksamin, dan vankomisin), pemakaian obat nefrotoksik (NSAIDs, golongan statin, amfetamin, fenofibrat, amfoterisin B, antivirus (asiklovir, sidofovir, indinavir, foskamet, tenofovir), pentamidin, diuretik, vankomisin, siklosporin, dan obat kemoterapi (sisplatin, ifosfamide, plicamycin, 5-fluorouracil, cytarabine, 6-thioguanine, metrotreksat), serta yodium (zat kontras).

Penelitian ini mencatat waktu timbulnya efek samping, yaitu gangguan pendengaran, gangguan fungsi ginjal, dan hipokalemia pasien TB RO dengan terapi kanamisin. Timbulnya efek samping dihubungkan dengan faktor risiko berdasar usia, riwayat pengobatan streptomisin sebelumnya, dan berat badan (menggunakan indeks massa tubuh (IMT)). Efek samping gangguan pendengaran tipe SNHL dengan hasil audiometri $\geq 26 \mathrm{~dB}$. Gangguan fungsi ginjal didapatkan kreatinin serum meningkat $\geq 0,3 \mathrm{mg} /$ dL (1,5-2 kali lipat) dari baseline. Hipokalemia dikategorikan dengan nilai kalium $<3,5 \mathrm{meq} / \mathrm{L}$. Data dasar diolah secara deskriptif. Angka kesintasan dan median kesintasan efek samping kanamisin dengan kaplan meier dan analisis cox regression untuk menilai faktor risiko (usia, berat badan, dan riwayat streptomisin) yang berpengaruh terhadap timbulnya efek samping. Semua uji statistik menggunakan nilai batas kepercayaan 95\% (95\% Indeks Kepercayaan) atau nilai batas kemaknaan $\mathrm{p}<0,05$.

\section{Hasil}

Penelitian dilakukan di ruang rekam medis RSUD Dr. Moewardi Surakarta. Pemilihan tempat 
Tabel 1 Karakteristik Dasar Subjek Penelitian

\begin{tabular}{lcc}
\hline Karakteristik & $\begin{array}{c}\text { Jumlah } \\
\text { (n=238) }\end{array}$ & $\begin{array}{c}\text { Persentase } \\
\text { (\%) }\end{array}$ \\
\hline Jenis kelamin & 105 & 44,1 \\
Laki-laki & 133 & 55,9 \\
Perempuan & & \\
Usia (tahun) & 8 & 3,4 \\
$\quad>59$ & 230 & 96,6 \\
$\quad \leq 59$ & & \\
Usia (tahun) & 8 & 3,4 \\
$>59$ & 137 & 57,5 \\
40-59 & 93 & 39,1 \\
$\quad<40$ & & \\
IMT* (kgBB/m ${ }^{2}$ ) & 153 & 64,3 \\
$<18,5$ & 85 & 35,7 \\
$\geq 18,5$ & & \\
Riwayat streptomisin & 119 & 50,0 \\
Ya & 119 & 50,0 \\
Tidak & &
\end{tabular}

*: Indeks massa tubuh

berdasar atas pertimbangan pencatatan rekam medis pasien TB RO. Hasil pencatatan rekam medis pasien TB RO didapatkan sebanyak 450 pasien TB RO, yang digunakan dalam penelitian 238 pasien TB RO. Hasil karakteristik dasar subjek penelitian pasien TB RO (Tabel 1).

Pasien TB RO berdasar atas Tabel 1 diketahui dari 238 pasien sebagian besar perempuan, yaitu 133 pasien $(55,9 \%)$. Usia pasien TB RO mayoritas $<40$ tahun, yaitu 93 pasien $(39,1 \%)$.
Indeks massa tubuh (IMT) mayoritas pasien TB R0 dalam kategori gizi kurang $\left(<18,5 \mathrm{kgBB} / \mathrm{m}^{2}\right)$, yaitu ada 153 pasien $(64,3 \%)$. Riwayat pasien mendapat obat suntik streptomisin dan tidak mendapat streptomisin masing-masing ada 119 pasien $(50 \%)$.

Efek samping dari gangguan pendengaran, gangguan fungsi ginjal dan hipokalemia pada pemberian kanamisin pasien TB RO dapat dilihat pada tabel satu. Pasien TB RO dari 238 orang terjadi gangguan pendengaran sebesar 143 pasien dan 23 pasien $(9,7 \%)$ terjadi gangguan pendengaran di bulan pertama. Angka kesintasan dari efek samping gangguan pendengaran adalah 39,9\% dengan median kesintasan 6 bulan. Gangguan fungsi ginjal didapatkan pada 147 pasien dan 30 pasien $(12,6 \%)$ yang terjadi pada bulan pertama. Angka kesintasan pasien dengan efek samping gangguan fungsi ginjal adalah 38,2\% dan median kesintasan 6 bulan. Hipokalemia didapatkan pada 169 pasien dan 64 pasien $(26,9 \%)$ terjadi di bulan pertama. Angka kesintasan pasien dari efek samping hipokalemia adalah 29,0\% dengan median kesintasan 3 bulan. Kurva kaplan meier pasien TB RO dengan efek samping gangguan pendengaran, gangguan fungsi ginjal dan hipokalemia (Gambar).

Pasien perempuan dapat berisiko mengalami gangguan pendengaran 1,549 kali lebih sering dibanding dengan laki-laki (IK 95\%; 1,0892,202). Usia $>59$ tahun memiliki risiko 4,865 kali lebih sering terjadi gangguan pendengaran dibanding dengan usia $<40$ tahun (IK 95\%; 2,294-10,317). Hasil analisis faktor risiko gangguan pada pendengaran dengan uji cox regression (Tabel 2).

Perempuan berisiko terjadi gangguan fungsi ginjal 1,667 kali lebih sering dibanding laki-laki

Tabel 2 Variabel yang Berpengaruh terhadap Gangguan Pendengaran dengan Analisis Cox Regression

\begin{tabular}{lcccc}
\hline & Variabel & HR & IK 95\% & p \\
\hline Jenis kelamin & Laki-laki & 1 & & 0,015 \\
Usia (tahun) & Perempuan & 1,549 & $1,089-2,202$ & 0,000 \\
& $<40$ & 1 & & 0,000 \\
IMT* $^{*}\left(\mathrm{kgBB} / \mathrm{m}^{2}\right)$ & $40-59$ & 2,419 & $1,716-3,409$ & 0,928 \\
& $>59$ & 4,865 & $2,294-10,317$ & \\
Riwayat streptomisin & $\geq 18,5$ & 1 & $0,695-1,394$ & 0,596 \\
\hline
\end{tabular}

*: Indeks massa tubuh 


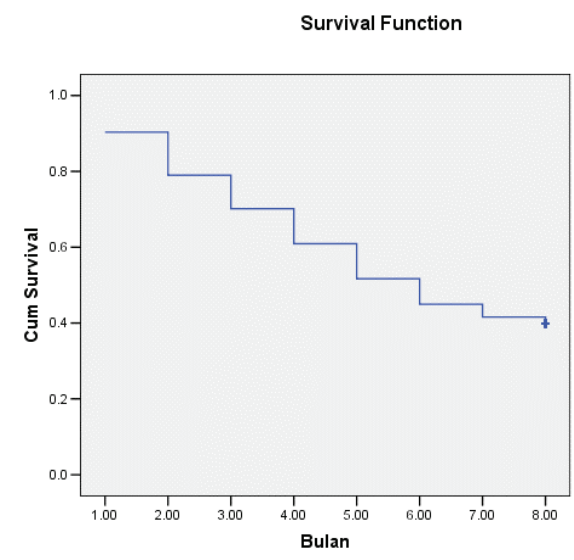

A. Gangguan Fungsi Ginjal

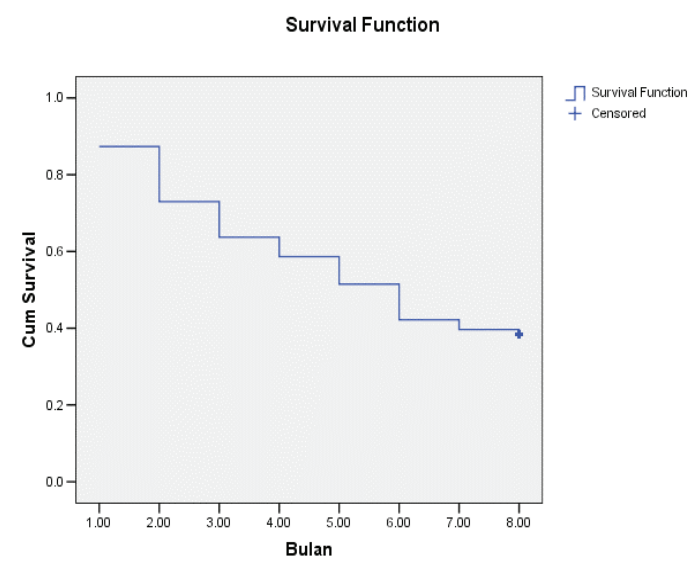

B. Gangguan Pendengaran

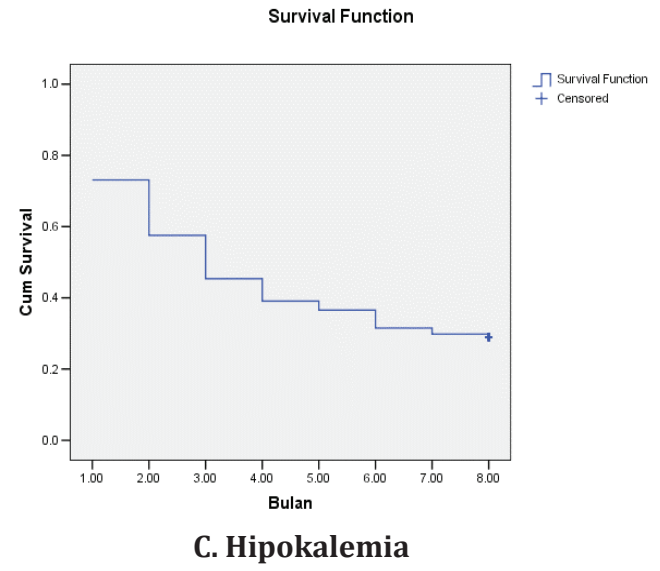

Gambar Kurva Kaplan Meier Efek Samping Kanamisin Pasien TB RO

Tabel 3 Variabel yang Berpengaruh terhadap Gangguan Fungsi Ginjal dengan Analisis Cox Regression

\begin{tabular}{llccc}
\hline & \multicolumn{1}{c}{ Variabel } & HR & IK 95\% & p \\
\hline Jenis kelamin & Laki-laki & 1 & & \\
Usia (tahun) & Perempuan & 1,667 & $1,179-2,357$ & 0,004 \\
& $<40$ & 1 & & \\
& $40-59$ & 1,892 & $1,353-2,646$ & 0,000 \\
IMT* $^{*}\left(\mathrm{kgBB} / \mathrm{m}^{2}\right)$ & $>59$ & 3,810 & $1,793-8,097$ & 0,001 \\
& $\geq 18,5$ & 1 & & \\
Riwayat streptomisin & $<18,5$ & 0,885 & $0,628-1,248$ & 0,487 \\
& Tidak ada & 1 & & \\
& Ada & 0,984 & $0,685-1,329$ & 0,782 \\
\hline
\end{tabular}

*: Indeks massa tubuh 
Tabel 4 Variabel yang Berpengaruh Terhadap Hipokalemia Dengan Analisis Cox Regression

\begin{tabular}{lcccc}
\hline & Variabel & HR & IK 95\% & p \\
\hline Jenis kelamin & Laki-laki & 1 & & \\
& Perempuan & 0,890 & $0,654-1,210$ & 0,457 \\
Usia (tahun) & $<40$ & 1 & & \\
& $40-59$ & 1,337 & $0,976-1,831$ & 0,071 \\
& $>59$ & 1,170 & $0,510-2,682$ & 0,771 \\
$\mathrm{IMT}^{*}\left(\mathrm{kgBB} / \mathrm{m}^{2}\right)$ & $\geq 18,5$ & 1 & & \\
& $<18,5$ & 1,146 & $0,830-1,582$ & 0,409 \\
Riwayat streptomisin & Tidak ada & 1 & & \\
& Ada & 1,040 & $0,767-1,410$ & 0,802 \\
\hline
\end{tabular}

*: Indeks massa tubuh

(95\% CI: 1,179-2,357). Usia > 59 tahun berisiko 3,810 kali lebih sering terjadi gangguan fungsi ginjal dibanding usia < 40 tahun (95\% CI:1,7938,097). Hasil analisis faktor risiko gangguan fungsi ginjal dengan uji cox regression pada pemberian kanamisin pasien TB RO (Tabel 3).

Hasil analisis cox regression efek samping hipokalemia pada pemberian kanamisin pasien TB RO tidak terdapat pengaruh signifikan dari semua faktor risiko. Hasil analisis faktor risiko hipokalemia dengan uji cox regression (Tabel 4).

\section{Pembahasan}

Kanamisin diberikan dengan cara sistemik dalam beberapa menit akan masuk ke dalam koklea dan bereaksi lalu membentuk metabolit ototoksik aktif yang menyebabkan apoptosis sel rambut bagian luar juga bagian dalam sehingga pemakaian jangka panjang akan menyebabkan gangguan pendengaran. ${ }^{9}$ Efek samping gangguan pendengaran awalnya timbul gangguan pada frekuensi tinggi dan juga berlanjut ke frekuensi rendah. ${ }^{4,6}$

Hasil penelitian pada 238 pasien terjadi gangguan pendengaran pada 143 pasien $(60,08 \%)$. Persentase dari timbulnya gangguan pendengaran penelitian ini hampir sama dengan penelitian oleh Reviono dkk. ${ }^{10}$ yang didapatkan efek samping gangguan pendengaran 59,6\% pada pasien pengobatan TB RO dari 114 pasien. Penelitian Sharma dkk. ${ }^{11}$ telah didapatkan ototoksisitas pada $18 \%$ kasus dan $2 \%$ timbul setelah minggu pertama pengobatan dan $12 \%$ setelah 6 minggu pengobatan kanamisin pada pasien TB MDR. Penelitian lainnya oleh Ramma dan Ibekwe ${ }^{12}$ didapatkan gangguan pendengaran sebanyak 25\% dan penelitian Mwansasu dkk. ${ }^{13}$ didapatkan gangguan pendengaran $80 \%$.

Penelitian ini didapatkan bahwa perempuan lebih berisiko terjadi gangguan pendengaran dibanding laki-laki. Penelitian oleh Sharma dkk. $^{11}$ dan Ramma dan Ibekwe ${ }^{12}$ didapatkan hasil bahwa jenis kelamin tidak didapatkan hubungan dengan gangguan pendengaran. Usia $>40$ tahun pada penelitian ini berisiko terjadi gangguan pendengaran dibanding dengan usia $<40$ tahun. Hasil penelitian ini sesuai dengan kepustakaan bahwa pemakaian pada usia tua merupakan salah satu faktor risiko timbulnya ototoksisitas pada pemberian kanamisin jangka panjang. ${ }^{6}$ Penelitian oleh Rakhmawati dkk. ${ }^{14}$ didapatkan hasil bahwa usia merupakan faktor yang memengaruhi gangguan pendengaran. Pertambahan usia berpengaruh pada proses degenerasi sehingga pasien lanjut usia lebih rentan terjadi gangguan pendengaran Hasil ini berbeda dengan penelitian sebelumnya oleh Ramma dan Ibekwe, ${ }^{2}$ serta Mwansasu dkk. ${ }^{13}$ usia tidak memiliki hubungan dengan gangguan pendengaran. Perbedaan pengaruh usia dengan gangguan pendengaran dapat dipengaruhi oleh karena perbedaan kategori usia dan lama pengamatan berbeda.

Kepustakaan menyatakan bahwa diperlukan kewaspadaan khusus untuk para pasien yang sebelumnya pernah mendapatkan pengobatan streptomisin berkaitan dengan risiko efek samping pada pemberian kanamisin pengobatan TB RO. ${ }^{3}$ Hasil penelitian sesuai dengan penelitian sebelumnya oleh Reviono dkk., ${ }^{10,15}$ yaitu tidak terdapat hubungan antara riwayat pemberian streptomisin sebelumnya dengan timbulnya gangguan pendengaran.

Indeks massa tubuh pada penelitian ini tidak berisiko terjadi efek samping gangguan pendengaran sama dengan hasil pada penelitian 
sebelumnya oleh Rakhamawati dkk., ${ }^{14}$ yaitu tidak didapatkan hubungan antara IMT dan gangguan pendengaran pada pengobatan TB RO. Hasil penelitian berbeda dengan penelitian Sagwa dkk yang menyatakan berat badan rendah saat baseline berpengaruh terhadap terjadinya gangguan pendengaran pada pasien TB MDR. ${ }^{16}$

Kanamisin terakumulasi dalam lisosom sel tubulus proksimal dan dapat mencapai 100 sampai 1.000 kali lebih tinggi dibanding dengan konsentrasi dalam serum. Kanamisin dalam tubulus proksimal masuk ke dalam sitosol, bekerja pada mitokondria menginduksi apoptosis, nekrosis, dan juga akan menghambat sejumlah transporter di tubulus proksimal yang memengaruhi reabsorbsi tubular dan viabilitas sel. Nekrosis tubuler mengakibatkan gangguan reabsorbsi tubuler serta osbstruksi tubuler kemudian akan menyebabkan penurunan GFR dan dapat mengakibatkan gangguan fungsi ginjal ditandai dengan peningkatan kreatinin serum.,17

Gangguan fungsi ginjal pada penelitian terjadi pada 147 pasien $(61,8 \%)$. Penelitian oleh Shin dkk. $^{18}$ didapatkan nefrotoksisitas pada 9,8\% pasien pada 4,8 bulan pengobatan TB MDR. Penelitian oleh Reviono dkk. ${ }^{15}$ didapatkan efek samping gangguan ginjal pasien TB MDR 59,6\% dari 114 pasien. Hasil penelitian didapatkan bahwa usia $>40$ tahun dan pasien perempuan lebih berisiko terjadi gangguan fungsi ginjal. Penelitian yang dilakukan oleh Reviono dkk. ${ }^{10}$ didapatkan bahwa pasien laki-laki lebih banyak mengalami gangguan fungsi ginjal. Kepustakaan menuliskan bahwa usia tua merupakan salah satu faktor risiko gangguan fungsi ginjal pada pemberian kanamisin.,17

Hasil penelitian mengenai riwayat pemberian streptomisin tidak berisiko terjadi gangguan fungsi ginjal. Penelitian sebelumnya oleh Reviono dkk. ${ }^{10}$ didapatkan hubungan signifikan antara riwayat pengobatan streptomisin dan efek samping gangguan fungsi ginjal. Pasien dengan IMT $<18,5$ pada penelitian ini tidak berisiko terjadinya efek samping gangguan fungsi ginjal. Hasil yang berbeda dari penelitian ini dapat disebabkan oleh perbedaan definisi gangguan fungsi ginjal yang digunakan, populasi yang berbeda dan pemakaian rejimen obat yang berbeda.

Hipokalemia merupakan gangguan elektrolit paling sering didapatkan. Penelitian oleh Shin S dkk. $^{8}$ dari 115 pasien TB MDR didapatkan 31,3\% hipokalemia setelah mendapat pengobatan 5,1 bulan.Penelitian oleh Reviono dkk. ${ }^{10}$ didapatkan efek samping hipokalemia pada pasien TB MDR $52,6 \%$ dari 114 pasien. Penelitian oleh Anggraini dkk. ${ }^{19}$ didapatkan hipokalemia sebanyak 57,9\% dengan rerata 2 bulan setelah mendapat terapi injeksi lini ke dua pada pasien TB MDR.

Hasil penelitian ini telah didapatkan bahwa variabel jenis kelamin, usia tua, IMT $<18,5$ $\mathrm{kg} / \mathrm{m}^{2}$ dan riwayat streptomisin sebelumnya tidak berisiko terhadap timbul efek samping hipokalemia. Penelitian sama dengan penelitian sebelumnya oleh Anggraini dkk. ${ }^{19}$ bahwa tidak didapatkan hubungan antara usia dan timbulnya efek samping hipokalemia pada pasien TB MDR dengan terapi injeksi lini ke dua. Penelitian oleh Reviono dkk. ${ }^{15}$ tidak didapatkan hubungan yang signifikan antara riwayatpemberian streptomisin dan efek samping hipokalemia. Penelitian oleh Anggraini dkk. ${ }^{19}$ juga didapatkan bahwa status nutrisi tidak berpengaruh terjadi hipokalemia pada pasien TB MDR yang mendapat pengobatan injeksi lini ke dua. Berbeda dengan penelitian oleh Shin dkk. ${ }^{18}$ didapatkan hubungan antara berat badan rendah pada awal pengobatan dengan terjadinya hipokalemia. Perbedaan hasil penelitian ini terjadi hipokalemia pada pasien yang mendapatkan terapi kanamisin pada TB RO berbeda dengan penelitian yang sebelumnya karena hipokalemia dipengaruhi oleh banyak faktor yang tidak dapat dihindari. Efek samping pemberian obat selain kanamisin pada terapi TB RO dapat menyebabkan diare, mual dan muntah juga berperan terhadap kehilangan elektrolit melalui saluran gastrointestinal. ${ }^{13,17}$

Keterbatasan penelitian, yaitu pada desain kohort retrospektif sehingga pengamatan yang dilakukan secara tidak langsung dan tidak dapat menunjukkan secara tepat waktu timbulnya efek samping kanamisin pada pengobatan TB RO. Perbandingan jumlah pasien pada karakteristik usia dan juga IMT pada penelitian ini kurang seimbang serta tidak menyingkirkan pengaruh faktor genetik yang mungkin memengaruhi hasil penelitian.

Simpulan, faktor usia tua dan jenis kelamin perempuan berpengaruh terhadap timbul efek samping kanamisin pada pengobatan TB RO berupa gangguan pendengaran dan gangguan fungsi ginjal. Faktor riwayat terapi streptomisin sebelumnya dan berat badan rendah (IMT $<18,5$ $\mathrm{kg} / \mathrm{m}^{2}$ ) tidak berpengaruh terhadap timbul efek samping pemberian kanamisin pada pengobatan TB RO. Pengawasan lebih ketat pada pasien usia tua ( $>40$ tahun) dan pasien perempuan terhadap efek samping gangguan pendengaran dan gangguan fungsi ginjal untuk memperkecil timbul efek samping kanamisin pada pengobatan TB RO. 


\section{Daftar Pustaka}

1. Kementerian Kesehatan RI Direktorat Jenderal Pencegahan dan Pengendalian Penyakit. Pengobatan pasien TB resisten obat. Jakarta: Kementerian kesehatan RI; 2016.

2. Garcia-Prats AJ, Schaaf HS, Hesseling AC. The safety and tolerability of the secondline injectable antituberculosis drugs in children. Expert Opinion Drug Safety. 2016:15(11):1491-500.

3. Heysell SK, Ahmed S, Rahman T, Akhanda W, Gleason AT, Ebers A, et al. Hearing loss with kanamycin treatment for multidrugresistant tuberculosis in Bangladesh. Eur Respir J. 2018:51(3):1-6.

4. Huth ME, Ricci AJ, Cheng AG. Mechanisms of aminoglycoside ototoxicity and targets of hair cell protection. Int J Otolaryngol. 2011;2011:1-19.

5. Leis JA, Rutka JA, Gold WL. Aminoglycosideinduced otoxicity. CMAJ. 2015:187(1):1.

6. Bardien S, Jong G, Schaaf HS, Harris T, Fagan J, Petersen L. Aminoglycoside-induced hearing loss: south African at risk. SAMJ. 2009;99(6):440-1.

7. Lopez-Novoa JM, Quiros Y, Vicente L, Morales AI. Lopez-Hernandez FJ. New insight into the mechanism of aminoglycoside nephrotoxicity: an integrative point of view. Kidney Int. 2011;79(1):33-45.

8. Shin S, Furin J, Alcantara F, Hyson A, Joseph K, Sanchez E, dkk. Hypokalemia among patients receiving treatment for multidrug-resistant tuberculosis. Chest. 2004;125(3):974-80.

9. Rybak LP, Brenner MJ. Vestibular and auditory ototoxicity. Dalam: Flint PW, Haughey BH, Lund VL, Niparko JK, Robbins KT, Thomas JR, dkk. Cummings otolaryngology head and neck surgery. Edisi ke-6. Philadelphia: Elsevier Saunders; 2015. hlm. 2369-82.

10. Reviono, Kusnanto P, Eko V, Pakiding $\mathrm{H}$, Nurwidiasih D. Multidrug resistant tuberculosis (MDR-TB): tinjauan epidemiologi dan faktor risiko efek samping obat anti tuberkulosis. MKB. 2014;46(4):
189-96.

11. Sharma V, Bhagat S, Verma B, Singh R, Singh S. Audilogical evaluation of patients taking kanamycin for multidrug resistant tuberculosis. Iranian J Otorhin. 2016; 28(3):203-8.

12. Ramma L, Ibekwe TS. Cochleo-vestibular clinical findings among drug resistant Tuberculosis Patients on therapy-a pilot study. Int Arch Med. 2012;5(3):1-5.

13. Mwansasu CS, Siziya S, Mpondo BCT. Hearing loss among multi drug resistant tuberculosis patients on kanamycin in Ndola teaching hospital, Zambia: study of ototoxicity and practice. Health Press Zambia Bull. 2017;1(4):72-8.

14. Rakhmawati L, Agustian RA, Wijana. Peluang kejadian ototoksisitas pada penggunaan kanamisin dalam pengobatan tuberkulosis resisten obat ganda selama satu bulan. MKB. 2015;7(4):22-30.

15. Reviono, Widayanto, Harsini, Aphridasari J, Sutanto YS. Streptomisin dan insidens penurunan pendengaran pada pasien multidrug resistant tuberculosis di rumah sakit dr. Moewardi. J Respir Indo. 2013;33(3): 167-72.

16. Sagwa EL, Ruswa N, Mavhunga F, Rennie T, Leufkens HGM, Mantel-Teeuwisse AK. Comparing amikacin and kanamycininduced hearing loss in multidrug-resistant tuberculosis treatment under programmatic conditions in a Namibian retrospective cohort. BMC Pharmac Toxic. 2015;16(36):19.

17. Wargo KA, Edwards JD. Aminoglycosideinduced nephrotoxicity. J Pharmacy Practice. 2014;27(6):573-7.

18. Shin SS, Pasechnikov AD, Gelmanova IY, Peremitin GG, Strelis AK, Mishustin S, dkk. Adverse reactions among patients being treated for MDR-TB in Tomsk, Russia. Int J Tuberc Lung Dis. 2007;11(12):1314-20.

19. Anggraini DH, Isbaniah F, Burhan E. Hypokalemia among multidrugs resistant tuberculosis patients. Respirology. 2017;22: 216-7. 